Journal of Science and Science Education

http://jppipa.unram.ac.id/index.php/jossed/index

\title{
The Diversity of Major Insect Pests at Sugarcane Development Center In Dompu Distrcit, West Nusa Tenggara
}

\author{
Muhammad Sarjan ${ }^{1 *}$, Muchlis², Irwan Muthahanas² \\ 1 Postgraduate, University of Mataram Jalan Pendidikan 31 Mataram, West Nusa Tnggara \\ 2 Study Program of Agroecotechnology,Faculty of Agriculture University of Mataram. Faculty of Agriculture, University of Mataram. Jl. \\ Majapahit No. 62 Mataram, West Nusa Tenggara, Indonesia.
}

DOI: $\underline{10.29303 / \text { jossed.v2i1.712 }}$

\section{Article Info}

Received : January $12^{\text {th }}, 2021$

Revised : April 20th, 2021

Accepted: April 27th, 2021

\begin{abstract}
Sugar cane (Saccharum officinarum Linn.) is a tropical plant that is very important because it can be used as one of the raw materials for making sugar. The development of sugar production in the last ten years has decreased by around $1.8 \%$ per year, this is due to several factors, one of which is due to the attack of sugarcane insect pests. Therefore, research was conducted to find out the diversity of important insect pests in sugarcane plants in the center of sugarcane development in the Dompu District. This research was conducted at the Pekat Sub District of Dompu District, West Nusa Tenggara. The method used is a descriptive method with data collection techniques directly and indirectly in the field at a number of observation points. Based on the observations there were 5 species of insect pests in the research area such as Valanga nigricornis, Locusta migratoria, Ceratovacuna lanigera, Scirchopaga nivella F., and Lepidiota stigma. Insect pests with the highest population and dominance are Ceratovacuna lanigera with an average population of 70 insect/plant and a domination index is 0.199808 . Locusta migratoria has a level of damage with criteria for moderate attack intensity, it is found in sugarcane plants aged 3 months. The results of this study indicate that Scirchopaga nivella F. and Lepidiota stigma F. insect pests have the potential as important pest insects on sugarcane crops.
\end{abstract}

Keywords: sugarcane; insect pest diversity; attack intensity.

Citation: Sarjan, M., Muchlis, M., \& Muthahanas, I. (2021). The Diversity of Major Insect Pests at Sugarcane Development Center In Dompu Distrcit, West Nusa Tenggara. Journal of Science and Science Education, 2(1), 38-46. doi:https://doi.org/10.29303/jossed.v2i1.712

\section{Introduction}

Sugarcane (Saccharum officinarum Linn.) as a tropical plant that is crucial because it can be used as a raw material for making sugar. Sugar produced from sugar cane is one of the nine staples that occupies an important position in people's lives (Handiyana, 2000).

Sugar is an important commodity for Indonesian and even for the world community. The benefits of sugar as a source of calories for the community apart from rice, corn, and tubers make sugar one of the staple food ingredients. The need for sugar from each country is not only to meet basic needs but also because sugar is the main sweetener used as a raw material in the food and beverage industry. The role of sugar is increasingly important due to the unavailability of artificial sweeteners that can replace the presence of sugar. Indonesia's geographic condition, which has the potential to produce sugar cane, has made Indonesia a country that has the potential to become the largest sugar producer in the world (Meireni, 2006).

The development of sugar production in the last ten years has decreased by about $1.8 \%$ per year. In 1994, the national sugar production reached 2.435 million tons, while in 2004 it was only 2.051 million tons. In the last decade, the lowest production occurred in 1998 with a production volume of 1.494 million tons. In 2015, there were a slight increase in production, namely 2.497 
million tons but the increase in production was not related to the production target set by AGI (Indonesian Sugar Association), which was 2.550 million tons. The production that has occurred in the last few decades has not been able to meet the demand for sugar for direct consumption of 2,820 tons and annual industrial needs of 2,740 tons. The need for sugar in Indonesia is always increasing every year and until now it has not been able to be fulfilled domestically, so that in meeting sugar needs every year Indonesia must import sugar, so that sugar needs can still be fulfilled every year, both for direct consumption and for industrial needs.

Therefore we need efforts to increase national sugar production optimally, namely through the National Sugar Self-Sufficiency program. To achieve national sugar self-sufficiency, programs to increase production, productivity, and quality of sugarcane crops are carried out sustainably. One form of increased production is by developing a sugar cane plantation area and building a factory to produce sugar, in West Nusa Tenggara Province in Pekat District, Dompu Regency, which has potential and strategic areas to develop a sugar cane plantation and sugar factory. In March 2014, a company PT. SMS (Sukses Mantap Sejahtera) which has built a sugar factory and has developed a sugarcane plantation in the area with an area of $\pm 5,000$ ha.

Concerning the problem of raw materials, namely the provision of high-quality sugarcane stalks is continuously carried out, either through intensification or extensification. Moreover, it must be studied more deeply the problems that become obstacles. One of them is the presence of insect pests, insects that are pests on sugarcane have various types and have high mobility. Pests have a habit of migrating to other areas when the environment is not supported so that it seems that these insect pests attack simultaneously and suddenly. This event usually occurs at the end of the rainy season which was preceded by a very long dry season. The damage caused by insect pests depends on the size of the pest population and the age of the sugarcane when attacked. According to information, it was explained that due to locust attack can reduce sugarcane weight by $14 \%$ and yield by $2.3 \%$. Losses caused by sugarcane pests in Indonesia are estimated at $75 \%$.

Research and Development (R\&D) (2014) stated that there are several important pests in sugarcane, namely shoot borer (Scirchopaga nivella Fabricus), uret (Lepidiota stigma F.), stem borer (Chilo sacchariphagus), Grasshopper (Oxya chinensis), Army worm caterpillar (Spodoptera litura F.), White Fleece Lice (Ceratovacuna lanigera), Shield Lice (Aulacaspis tegalensis), Termites (Macrotermes sp.) (R\&D, 2014). Sugarcane plantations in Dompu Regency, which is a new sugarcane plantation development area, the possibility of developing a variety of pests and an increase in pest populations will still occur following plant growth and environmental conditions in the sugarcane plantation area, in terms of enriching the information about the existence of Pests. Not many other pests attack sugarcane while the plantation development activities are continuing. Therefore, based on this consideration, it is necessary to conduct a study that aims to determine the diversity of important insect pests in sugarcane at the sugarcane development center of the Dompu Districk. This result of research is expected to be used as a database regarding the diversity of important insect pests on sugarcane so that it can be used to control pests on sugarcane.

\section{Method}

This study used descriptive methods with data collection techniques directly and indirectly in the field at several observation points. This research was in Pekat SubDistrict, Dompu District, West Nusa Tenggara. The materials used in this study were $70 \%$ alcohol, water, and detergent. Meanwhile, the tools used in this study are yellow pan traps, pitfall traps, small brushes, loupe, tape measure, raffia rope, scissors, bamboo stakes, cameras and stationery.

\section{Research Implementation \\ Location of Survey}

The research location of survey was conducted at several sugarcane planting locations in Pekat Sub District, Dompu District.

\section{Plotting Area}

Plotting is the determination of the observation points of sample plants that have been used as objects of observation. The determination of the sample plants was divided into 3 observation points with 3 different age variants, at 1 observation point there were 12 observation units so that at 3 observation points there were 24 observation units, each observation point was observed diagonally $5 \%$ of the plant population.

\section{Trap Installation}

The traps used are yellow pan traps and pitfall traps. The traps are placed for sampling using a systematic diagonal system, according to the sampling model. For every 3 age variants of sugarcane plants, 4 yellow pan traps and 4 pitfall traps were placed at each observation point and placed randomly.

\section{Parameters Observation}

The parameters observed in the study were (1) population size, (2) diversity of species, (3) dominance, 
and (4) intensity of attack from pests on sugarcane, then the supporting parameters, namely temperature, and humidity. Observations were made with 5 day observation time intervals.

\section{Data analysis \\ Pest Populations}

Observation of pest populations was carried out by sampling techniques with a system of calculating the number of pests in each sample plant directly in the field. The calculation of the pest population is done by counting the individual number of pests on sugarcane. Observation of the number of individuals (nymphs) of insect pests is by counting directly on the sample plants.

\section{Pest Dominance}

The calculation of pest dominance is to see the most dominant pests on sugarcane. To determine the dominant pest, it can be calculated using the dominance index (C) of Simpson (Southwood, 1978; Ludwig and Reynold, 1998).

$$
\mathrm{C}=\Sigma(\mathrm{in} / \mathrm{N})^{2}
$$

Information :

In: The total number of individuals of a species;

$\mathrm{N}$ : The total number of individuals from all species;

\section{Level of Damage}

Observation of the intensity of attack (level of damage) pests is carried out by observing the intensity of the general attack of pests on each sample plant. Observations were made with the observation time interval every 5 days. To calculate the relative attack intensity (level of damage) is to use the formula according to Townsend and Heuberger (1943):

$$
P=\frac{\Sigma\left(n_{1} x v_{i}\right)}{\mathrm{ZnN}} \times 100 \%
$$

Information :

P: Damage rate (\%);

ni: The number of plants or plant parts observed from each attack category;

vi: A scale value of each attack category;

$Z$ : The highest attack category scale;

$\mathrm{N}$ : The number of plants or plant parts observed;

Attack category value (v):

0 : No damage

1: Damage $>0-25 \%$

2: Damage $>25-50 \%$

3: Damage $>50-75 \%$

4: Damage $>75-100 \%$
The criteria for the attack are determined in Table 1.

Table 1. The criteria for the attack

\begin{tabular}{lll} 
No & Damage Level & Criteria \\
\hline 1 & 0 & No Damage \\
2 & $>0-25 \%$ & Low \\
3 & $>25-50 \%$ & Moderate \\
4 & $>50-75 \%$ & Heavy \\
5 & $>75 \%$ & Very Heavy
\end{tabular}

\section{Result and Discussion}

\section{Pest Insect Diversity}

Table 2. Pest Insect Diversity

\begin{tabular}{lll}
\hline Pest Insects & Damage level & information \\
\hline Valanga nigricornis & 16.56 & Heavy \\
Locusta migratoria & 0.14 & Low \\
Ceratovacuna lanigera & 41.95 & Very Heavy \\
Scirchopaga nivella & 1.03 & Moderate \\
Lepidiota stigma & 0.75 & Low \\
\hline
\end{tabular}

From the results of the analysis of the Shannon diversity index value $\left(\mathrm{H}^{\prime}\right)$, which is shown in Table 2, the diversity index value of insect pests on sugarcane is high, with the range $\mathrm{H}>3$.

The high and low diversity of insect pests depends on potential points and environmental barriers (physical, biotic, and food factors). The existence of one type of host plant allows certain types of insect pests to be in one place. The availability of host plants continuously in abundance will support the growth of pest populations.

\section{Pest Insect Characteristics and Symptoms of Attack on Sugarcane Plants.}

The existence of insects that can disrupt the growth and development of cultivated plants are insects that are classified as insect pests. Some of the insect pests on sugarcane in the Dompu Regency that were found during the observation were grasshoppers, white hair lice, shoot borer, and uret.

The Wood Grasshopper (Valanga nigricornis) and the Wandering Grasshopper (Locusta migratoria).

There were two types of grasshoppers that attack sugarcane, such as Locusta migratoria and Valanga nigricornis. This type of pest attacks sugarcane when it is young, by eating the shoots and leaves of the sugarcane plant (just growing). From the observations in the field, it is known that among the two grasshoppers the most found and giving the most symptoms of damage is the locusta migratoria. Wandering grasshoppers tend to form large groups and like to move (immigrate) so that in a short time 
they can spread over a large area. Groups that immigrate can eat plants that they pass along on their way. The eating behavior of adult wandering grasshoppers is usually when they alight in the afternoon until evening and in the morning before flying (Kalshoven, 1981).

The development of grasshopper colonies is known to experience 3 phases of population growth, namely the solitary phase, the transient phase, and the gregarious phase. In the solitary phase, grasshoppers live independently and do not cause damage and loss to plants. In the gregarious phase, grasshoppers live in large groups, move around and cause massive damage to plants as well. The phase change from solitary to gregarius and vice versa from gregarious to solitary is influenced by climatic conditions through a phase called the transient phase (Yunus, 2015).
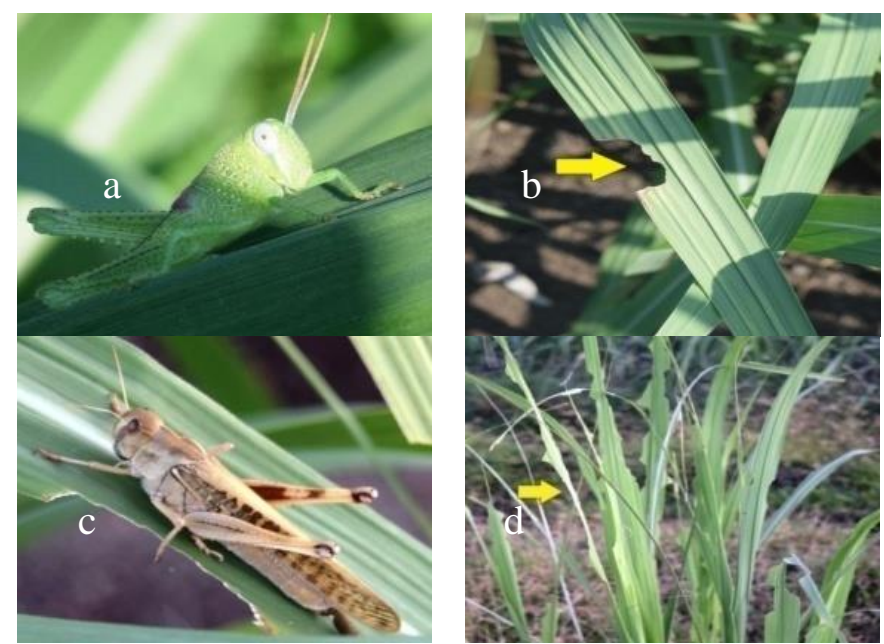

Figure 1. (a) Wood Grasshopper (Valanga nigricornis) (b) Symptoms of a Valanga nigricornis attack (c) Wandering Grasshopper (Locusta migratoria) (d) Symptoms of a Locusta migartoria attack. (Source: Research Documentation).

The difference in attack symptoms between Valanga nigricornis and Locusta migratoria is a sign that the two grasshoppers are in different colony phases, Valanga nigricornis does not provide a large level of damage and has a low population level. It is found in plantations that are not clustered or live separately respectively individual. So, that Valanga nigricornis is a grasshopper that is in the "Solitary" colony phase. Whereas Locusta migratoria gives major symptoms of damage to the sugarcane plant and only leaves the leaf-veins and Locusta migratoria seen in the study sites live in groups. Therefore, it is stated that the grasshoppers are in the "Gregarius" phase.

\section{Top Borer (Scirchopaga nivella F.)}

The young caterpillars (larvae) of the shoot borer are grayish in color, then as adults turn brownish. This caterpillar is less than $20 \mathrm{~mm}$ long. This pest attacks sugarcane from 2 weeks of age shoots until the mature sugarcane plants are ready for cutting.
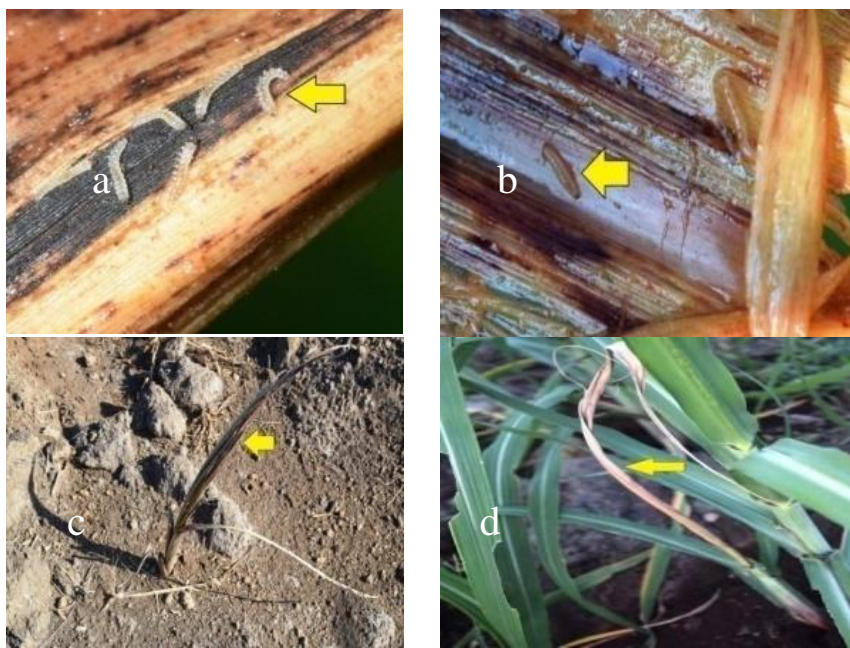

Figure 2. (a) Shoot Borer Larvae (b) Symptoms of Top Borer Attack. (Source: Research Documentation)

Symptoms of shoot borer attack found in locations have different levels of damage to the sugarcane plants, this can be seen from the varying ages of sugarcane plants on each land. In sugarcane plants that are 3 months old, the symptoms of shoot borer attack have caused all parts of the sugarcane to die, so they can no longer carry out further growth. While the symptoms of attack seen in sugarcane plants that are around 6 months and 1 year old have a moderate level of damage, and the plants continue to process growth and development. But this can cause sugarcane plants to produce less sugar because the availability of stored sucrose is reduced due to growth activity and new shoot development.

\section{White Fleas (Ceratovacuna lanigera)}
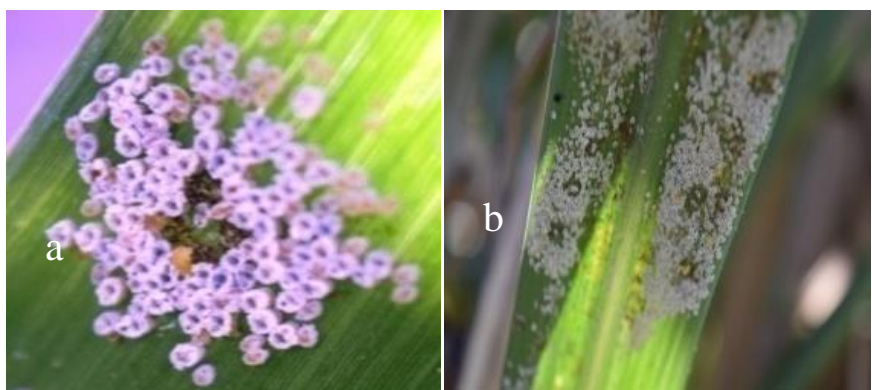

Gambar 3. White Fleas (Ceratovacuna lanigera). (Source: Research Documentation)

The white Fleas found at the observation location were at the tick and wingless insect stage. The insect's body surface were observed in a large population or grouping. To know the symptoms of C. lanigera attack 
on sugarcane, it can be indicated by the presence of the white fleas under the leaf surface, and the sugarcane leaves will dry out if the damage is ignored for long time.

The white fleas attacks sugarcane by sucking the leaf juices (sap). The dirt excreted by the fleas is a good medium for the growth of white fleas. It grows and develops by covering the leaf surface so that it disrupts the photosynthetic process of sugarcane. Further attacks of that pest cause stunted sugarcane plants, death of young shoots, reduce yields and sugar content by sucking liquid or sap from leaves, then emitting honeydew dung which invites the presence of ants and sooty molds (Litbang, 2014).

\section{Grub (Lepidiota stigma F.)}

Lepidiota stigma $\mathrm{F}$. is one of the most important pests of sugarcane that can cause stunted plants and collapse because they cause a loss of up to $50 \%$ sugar yield. Based on the observations, it is known that the larvae of these pests live in the soil or in the area around the roots of the plant which is filled with leaf litter and plant stems. The larvae of the pests are characterized by a shiny grayish-white color, the tail is black and specifically, the head is yellow and has 3 pairs of legs.
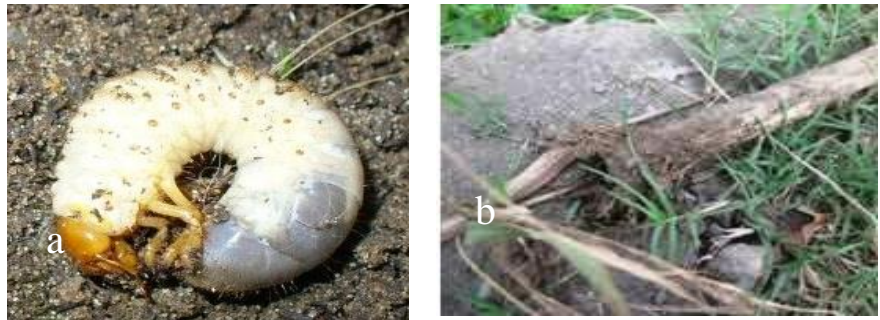

Figure 4. (a) Grub (Lepidiota stigma F.) (b) attack symptom (Sumber: www.kaskus.co.id)

Based on field observations, the symptoms that was shown by the pests (Lepidiota stigma F.) on sugarcane was plant shoots wither then it turned yellow. It is similar to symptoms caused by drought. If the sugarcane plant is pulled out, some of the roots of the plant are damaged in an intact condition. The roots looked short (broken) and there were uretic bites. On a new attack, the uret pests will be seen in the root area of the sugarcane plant

\section{Population and Domination of Sugarcane Pests in Dompu District}

Table 3. The average insect population of Valanga nigricornis, Locusta migratoria, Scirchopaga nivella F., Ceratovacuna lanigera and Lepidiota stigma at three ages of sugarcane plants in Dompu Regency during the observation.

\begin{tabular}{lllllll}
\hline No & $\begin{array}{l}\text { Plant } \\
\text { Age }\end{array}$ & $\begin{array}{l}\text { Valanga } \\
\text { nigricornis }\end{array}$ & $\begin{array}{l}\text { Locusta } \\
\text { migratoria }\end{array}$ & $\begin{array}{l}\text { Scirchopaga } \\
\text { nivella F. }\end{array}$ & $\begin{array}{l}\text { Ceratovacuna } \\
\text { lanigera }\end{array}$ & \begin{tabular}{l} 
Lepidiota stigma \\
\hline 1
\end{tabular} \\
\hline 1 years & - & - & - & 127 & 12 \\
3 & 6 months & 71 & 14 & 39 & 83 & - \\
Sum & 3 months & 83 & 18 & 22 & - & - \\
Average & 154 & 51,33 & 10,66 & 61 & 210 & 12 \\
\hline
\end{tabular}

The number of each insect pest population in different plant age is shown in Table 3 . The average population of insect pests of white flea (Ceratovacuna lanigera) was 70 individuals/plant, wood grasshopper (Valanga nigricornis) 51.33 individuals/plant, grasshopper locust (Locusta migratoria) 10.66 individuals/plant, shoot borer (Scirchopaga nivella F.) 20.33 individuals/plant, and uret (Lepidiota stigma) 4 individuals/plant. The presence of pest insect populations in an ecosystem is never constant or fluctuating in a certain period with different plant ages and conditions. Therefore, the population sometimes can be either high low dipends on its environmental condition.

According to Anonymous (2005b), one of the most important pests in sugarcane is $C$. lanigera which population increases at the beginning of the rainy season. C. lanigera reproduces by parthenogenesis. Based on the population data in Table 3., C. Lanigera's population was higher than Lepidoptera stigma at the age of 1 years, while in 3-month-old V. Nigricornis tended the highest number of pest population. The high number of $C$. Lanigera was caused by the abundant of food available in the field.

Table 4. The dominance of Insects in Sugarcane in Dompu District.

\begin{tabular}{lll}
\hline No & Pest Insect & Dominance index \\
\hline 1 & Valanga nigricornis & 0.107584 \\
2 & Locusta migratoria & 0.004624 \\
3 & Ceratovacuna lanigera & 0.199809 \\
4 & Scirchopaga nivella & 0.016916 \\
5 & Lepidiota stigma & 0.000625 \\
\hline
\end{tabular}


Based on the data, the insect pest Ceratovacuna lanigera tended the highest dominance level among other insects observed which was 0.199809. However, comparing to Odum's (1993) statement, it said that the dominance criteria of $(\mathrm{D}<0.5)$ means that the dominance of the insect pest Ceratovacuna lanigera is in a low category. Due to this low category, the impact of the insect pest Ceratovacuna lanigera is not at a dangerous stage. The presence of dominant and unexpected pests was caused by a competition among the five insects, especially in obtaining food. The availability of food or host plants lead to a lot of insects that would continue to spread. However, if the food (host plant) is damaged by several insects, it can cause the limit source of food for each insect species. This also causes high competition among the five insects. To be more General, stronger insects will be able to continue its lifecycle and can be spreaded easily.

Untung (2010) said "there are some factors that are less important in determining the population and dominance of an insect pest which are abiotic factors such as temperature, humidity, and wind. Abiotic factors can bring a population closer to (more or less) than the equilibrium level. If the temperature conditions are not suitable for insect life, it can cause the insect population to decline away from its equilibrium level. After this happens, the abiotic factor will return the population to its equilibrium level. If the weather conditions are very favorable for the life and reproduction of a pest, it will be able to encourage the population to increase rapidly beyond the equilibrium level".

\section{The intensity of sugarcane pests in Dompu Regency.}

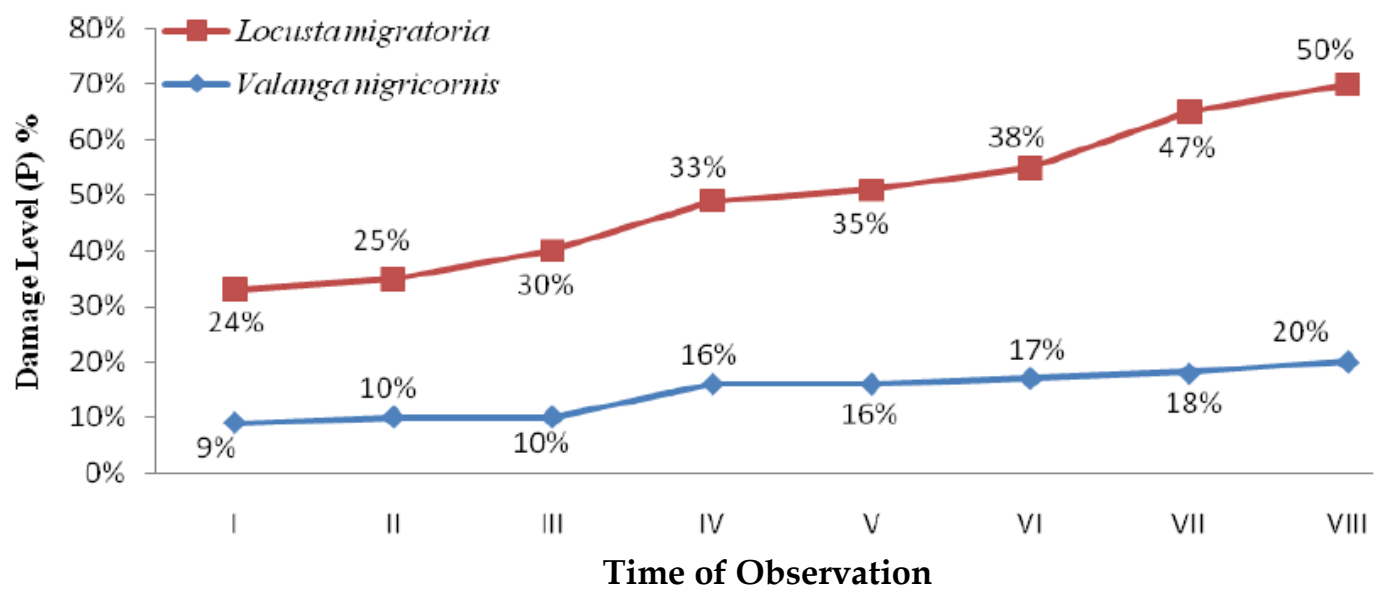

Figure 5. The intensity of the attack of wood grasshopper (Valanga nigricornis) and Kembara grasshopper (Locusta migratoria) on 3-month-old sugarcane.

Observation of the intensity of relative pest attacks was carried out on sugarcane plants aged 1 year, 6 months, and 3 months. The intensity of the attack of wood grasshopper (Valanga nigroconis) on 3month-old sugarcane has a percentage level of damage (P) with the attack intensity of $9 \%-10 \%$. Further observations, the intensity of the attacks continued to increase significantly at the fourth observation to the seventh observation by $16 \%-18 \%$ respectively. In the 8th observation, the intensity of the attack continued to increase from the previous observation which was $20 \%$. Whereas for the locust insect (Locusta migratoria), the level of damage $(\mathrm{P})$ in the I and II observations had a damage intensity of $24 \%-25 \%$. The third observation to the seventh observation, the attack intensity continued to increase by $30 \%-47 \%$. The VIII attack intensity continued to increase and the damage rate was obtained by $50 \%$ (Figure 5 .). 


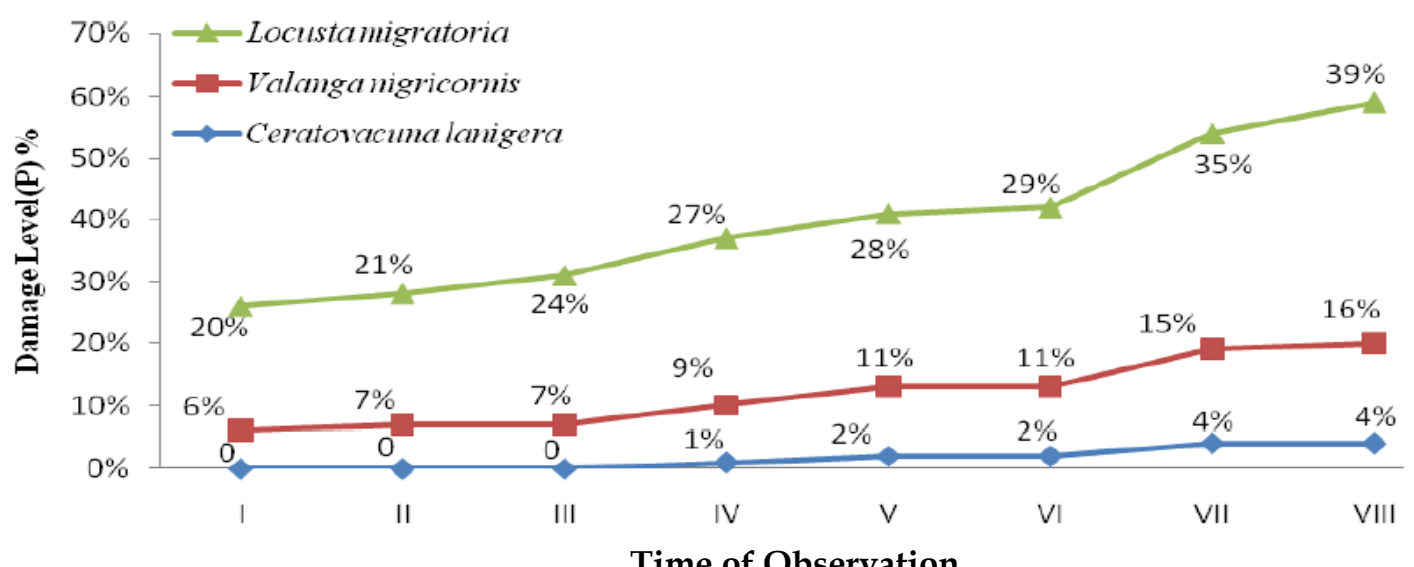

Figure 6. The intensity of attack of wood grasshopper (Valanga nigricornis), Kembara grasshopper (Locusta migratoria), and white furlice (Ceratovacuna lanigera) on 6-month-old sugarcane

The line graph shows the intensity of the attack of pest insects found. The wood grasshopper (Valanga nigricornis) on 6 months old sugarcane obtained a percentage level of damage $(\mathrm{P})$ in an observation I with an attack intensity of $6 \%$. In the second and third observations, the intensity of the attack increased by $7 \%$, and from the fourth to the seventh observation, the percentage of attack intensity increased significantly, which was $9 \%-15 \%$. The VIII observation the intensity of the attack continued to increase from the previous observation to $16 \%$ (Figure 6.).

The level of damage (P) caused by the Locusta migratoria in the first observation obtained a percentage of the attack intensity of $20 \%$. In the next observations, the intensity of the attack continued to increase with a percentage of $21 \%-39 \%$ (Figure 4.7.). The level of damage $(\mathrm{P})$ caused by the white head lice insect (Ceratovacuna lanigera) was seen in the fourth observation with the attack intensity that was still low which was $1 \%$. In the observation V and VI the attack intensity increased to $2 \%$. Then in the 7 th observation and the VIII observation, the percentage of attack intensity damage was $4 \%$ (Figure 6.).

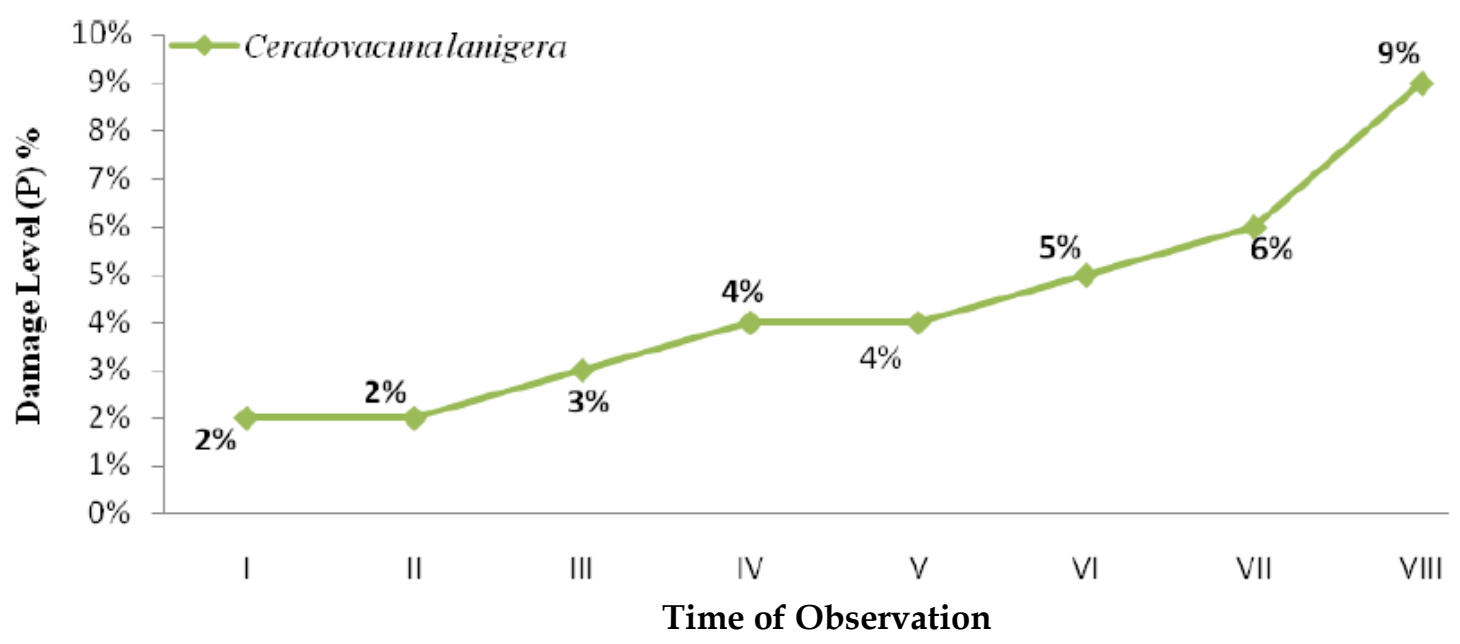

Figure 7 . Intensity of White Flea (Ceratovacuna lanigera) Pest Attack on 1-Year-Old Sugarcane Plants.

Based on the line graph (Figure 7.), The percentage of damage level $(\mathrm{P})$ was obtained in observations I and II with low attack intensity of $2 \%$. Subsequent observations were the third observation to the seventh observation, the intensity of the attack continued to increase to $3 \%-6 \%$. Following that, in the eighth observation, the intensity of the attack continued to increase to $9 \%$.

The relative attack intensity of the three sugarcane plant ages can be seen that the Locusta migratoria and the Valanga nigricornis were commonly found in sugarcane plants aged 3 months and 6 months. Anonymous (2005b) states that this pest has a habit of 
migrating to another environment if the environment is not supportive, so it seems that these grasshoppers attack simultaneously and suddenly. In addition, the density of the polyphagous insect population is strongly influenced by the planting conditions itself, such as the number of weeds that can be used as hiding places, and the soil moisture is high enough, so insects can grow up.

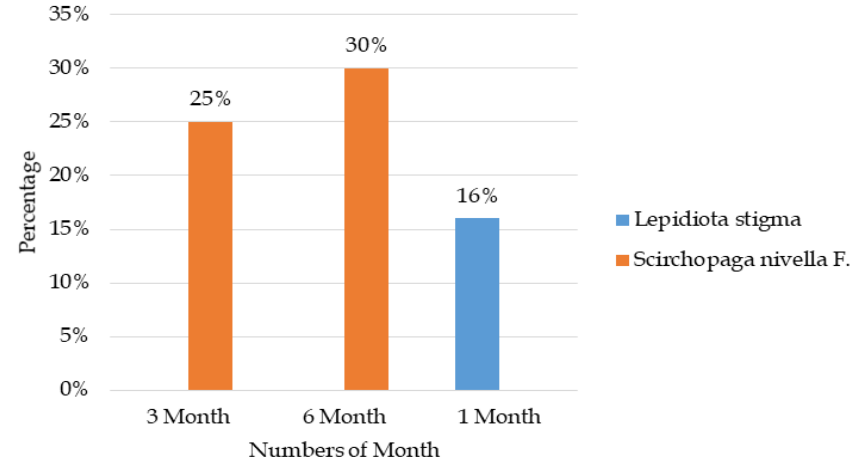

Figure 8. Pest Insect Absolute Attack Intensity on 3 months, 6 months, and 1-year-old sugarcane plants

The observation of absolute attack intensity on sugarcane plants of 3 different ages show that there were some insect pests that have the potential to cause physical damage to the plant. Further effect can result in economic losses. Based on the results of observations and analysis of the absolute attack intensity on 1-yearold sugarcane, it was found that Lepidiota stigma was a pest with an attack intensity of $16 \%$. Whereas in sugarcane plants that are 3 months and 6 months old, there are shoot borer insects (Scrichopaga nivella F.) which have a higher attack intensity than uret pests (Lepidiota stigma) which is 30\% in sugarcane plants aged 6 months and 25. \% for 3-month-old sugarcane (Figure 8.). The high intensity of shoot borer insect attacks (Scrichopaga nivella F.) on 3 months and 6 months of sugarcane is due to the morphological and anatomical characteristics of sugarcane which have a correlation with shoot borer attack, sugarcane with hard leaf bones or leaf bones with many grooves in the epidermis. The bottom is more resistant to shoot borer attack. Abuse can reduce shoot borer attack. The ability to attack shoot borer is also influenced by plant age where shoot borer generally attacks young plants in age of about 2 months (Anonymous, 1995).

The level of shoot borer attack on sugarcane in the field is more influenced by the level of rainfall than the type of sugarcane. The higher the rainfall, the shoot borer attack tends to increase. High rainfall increases soil moisture and is an excellent place for its development (Wirioatmodjo, 1978; Afolabi et al., 2009).

\section{Conclusion}

Based on the results of the research, it was concluded that: (1) There are 5 species of insect pests associated with sugarcane; Valanga nigricornis, Locusta migratoria, Ceratovacuna lanigera, Scirchopaga nivella F., and Lepiodata stigma; (2) Pests with the highest population and dominance was Ceratovacuna lanigera with a population mean of 70 insects/plant and a dominance index of 0.199808; (3) High attack intensity was caused by the insect pest Locusta migratoria with a level of damage up to $50 \%$ on 3-month-old ofsugarcane. Scirchopaga nivella F. and Lepiodata stigma have potential as important insect pests on sugarcane.

\section{Acknowledgements}

Many thanks are addressing to the official and filed worker of PT. SMS (Sukses Mantap Sejahtera) as well as the official of Regional office of Agriculture and Astate Crop, West Nusa Tenggara Province and Dompu District who always providing the data and information during this investigation.

\section{References}

Afolabi, L. A., Omonijo, A. G., \& Aderibigbe, A. T. B. (2009). Effects of rainfall patterns on soil moisture, soil temperature and plant growth in humid forest zone, Nigeria. American-Eurasian Journal of Sustainable Agriculture, 3(3), 413-417.

Anonymous. (2009). Pests and Plant Diseases. Self-help spreader. Bogor.

Anonymous. (2005b). Entomology. Faculty of Math and Science. Airlangga University Surabaya.

Anonymous. (1995). Guidelines for Sugarcane Cultivation. PT Perkebunan X PG Poerwodadi. Madiun.

Djasmin. (1984). Peoples Sugarcane Pests. PTP.XXI-XXII Persero. Surabaya.

Handiyana. (2000). Plant Pest Science Teaching Materials. Padjadjaran University. Bandung.

Kalshoven, L.G.E. (1981). The Pests of Crops in Indonesia. (edited by PA. Van Der Laan). PT. Ichtiar Baru Van Hoeve, Jakarta.

R\&D. (2014). Report on Industrial Crops Research and Development. Bogor.

Meireni. (2006). Application of IPM Technology in Sugarcane Plants. Horticultural Crops Research Institute. Bandung.

Mulyana, W. (2001). Theory and Practice of Suitable Planting Sugarcane with All Its Problems. Various Sciences, Semarang. 
Odum, E.P. (1993). Basics of Ecology. Translator: Samingan $\mathrm{Tj}$, Gadjah Mada University Press. Yogyakarta.

PTPN VII. (1997). Sugarcane Vademecum. Bandar Lampung.

Southwood, A. (1978). Diktat Lecture on Forest Pests. Development Foundation Faculty of Forestry UGM, Yogyakarta

Supriyadi. A. (1992). Sugarcane Rendement: The Meanders of the Problem. Kanisius, Yogyakarta.

Untung, K. (2010). Dictate of Basics of Plant Pest Science. Faculty of Agriculture UGM. Yogyakarta.

Wirioatmodjo. B. (1978). Some Problems Faced In Eradicating Uret In Sugarcane. BP3G Bulletin. Issue 77. Page: 1-13.

Yunus, B. (2015). Population of Main Pests on Rice Plants (Thesis). Hasanuddin University. Makassar 